ISSN: 0213-2087 eISSN: 2444-7080

DOI: https://doi.org/10.14201/shhc20213993120

\title{
MARRUECOS, 1911: EN TORNO A LA CRISIS DE AGADIR Y LAS CRÓNICAS DE ABDELKRIM EN EL TELEGRAMA DEL RIF (MAYO-NOVIEMBRE DE 1911)*
}

\author{
Morocco, 1911: An approach to the Agadir crisis \\ and Abdelkrim's Arabic chronicles on El Telegrama \\ del Rif (May-November 1911)
}

\author{
Rocío VELASCO DE CASTRO \\ Universidad de Extremadura \\ https://orcid.org/0000-0003-0377-4100
}

Recibido: 22/03/2021 Revisado: 25/05/2021 Aceptado: 21/06/2021

RESUMEN: Este trabajo pretende contribuir al estudio de la historia de las relaciones hispano-marroquíes y de la figura de Abdelkrim, Personaje controvertido que pasó de cantar las virtudes de la empresa colonial española a combatirla. El trabajo, que aúna el enfoque histórico con el filológico, tiene como objetivos analizar las repercusiones en clave interna e internacional de la denominada crisis de Agadir y enmarcar en este contexto la labor del rifeño como cronista en El Telegrama del Rif. Partiendo del contexto histórico que desembocó en dicho episodio, considerado por un lado como la antesala del tratado franco-marroquí de Fez de 1912, y por otro como antecedente de la primera guerra mundial, el texto realiza una primera aproximación a la contribución de Abdelkrim a la difusión de la posición española a través de sus crónicas, todas ellas escritas en árabe. Con ello se pretende ofrecer

* Este trabajo se inscribe en el proyecto EtniXX: «Discursos y representaciones de la etnicidad: política, identidad y conflicto en el siglo xX" (Ref. PID2019-105741GB-I00), subvencionado por el Ministerio de Ciencia e Innovación a través del programa de ayudas a proyectos de I+D+i en el marco de los programas estatales de generación de conocimiento y fortalecimiento científico y tecnológico del sistema de I+D+i orientada a los retos de la sociedad, convocatoria 2019 
una muestra de cómo un medio de carácter militar y colonialista justificó las actuaciones españolas durante la crisis y en qué medida la inestimable colaboración de Abdelkrim ayudó a ello.

Palabras clave: Marruecos; Colonialismo; Crisis de Agadir; Abdelkrim; El Telegrama del Rif.

ABSTRACT: This paper aims to promote the study of Spanish-Moroccan relations and the figure of Abdelkrim as a controversial character who went from singing the virtues of the Spanish colonial undertaking to fighting it. This paper aims to analyse the internal and international impact of the so-called Agadir crisis as well as to frame the Riffian's work as a chronicler in El Telegrama del Rif during this period. Starting from the historical context which led to this episode, considered on the one hand as the prelude to the Franco-Moroccan treaty of Fez of 1912, and on the other as an antechamber to the First World War, the text, which combines historical and philological analysis, provides a first approach to Abdelkrim's contribution to spreading the Spanish position through his chronicles, all of them written in Arabic. This is intended to provide a sample of how a military and colonial media press justified Spanish actions during the crisis and to what extent Abdelkrim's invaluable collaboration helped to do so.

Key words: Morocco; Colonialism; Agadir Crisis; Abdelkrim; El Telegrama del Rif.

\section{ANTECEDENTES Y CONTEXTUALIZACIÓN DE LA CRISIS}

Al comenzar el siglo xx España pasaba por un momento de especial debilidad tanto a nivel nacional como internacional. La pérdida de Cuba, Puerto Rico y Filipinas agudizó la crisis política y de identidad nacional que se había manifestado con fuerza desde la segunda mitad del siglo XIX ${ }^{1}$. Ya entonces la frustración generada había tratado de mitigarse retomando el interés por la cuestión marroquí a través de la que fue bautizada con intencionada grandilocuencia como Guerra de África (18591860) ${ }^{2}$. Su cobertura en prensa, además de su eco en medios artísticos y literarios,

1. Martín Corrales, Eloy: «El patriotismo liberal español contra Marruecos (1814-1848). Antecedentes de la Guerra de África de 1859-1860", Illes i imperis: Estudios de historia de las sociedades en el mundo colonial y post-colonial, 7, 2004, pp. 11-44.

2. Además de las conocidas posiciones adoptadas por Pedro Antonio de Alarcón y Benito Pérez Galdós, para un análisis pormenorizado, tanto de las motivaciones internas como de la coyuntura internacional que desembocaron en esta incursión militar, consúltese García BaLAÑá, Albert: "Patriotismos trasatlánticos. Raza y nación en el impacto de la Guerra de África en el Caribe español de 1860", Ayer, 106, 2017, pp. 207-237; GARrido GujJARro, Óscar: Aproximación a los antecedentes, las causas y las consecuencias de la Guerra de África (1859-1860) desde las comunicaciones entre la diplomacia española y el Ministerio de Estado. Tesis Doctoral. Madrid: uned, 2014; MechBAL, Adnan: Los orígenes de la Guerra de áfrica (1859-1860). Tesis Doctoral. Madrid: unED, 1993; VeLAsCo De Castro, Rocío: "Objetivos y limitaciones de la política exterior española en Marruecos: la batalla de Tetuán (1859-1860)", Revista Historia Autónoma, 2, 2013, pp. 93-106. 


\section{ROCÍO VELASCO DE CASTRO \\ MARRUECOS, 1911: EN TORNO A LA CRISIS DE AGADIR Y LAS CRÓNICAS \\ DE ABDELKRIM EN EL TELEGRAMA DEL RIF (MAYO-NOVIEMBRE DE 1911)}

marcó la senda que seguirían años más tarde los defensores de la empresa colonial y con ello, de la conquista militar del territorio. De esta forma, la participación española en el proceso de descomposición del sultanato marroquí se consolidó a partir del tratado de Wad-Ras ${ }^{3}$ (1860), con el que se dio por finalizada la contienda ${ }^{4}$.

Desde un punto de vista ideológico, su justificación ante la opinión pública también se reflejó en el plano lingüístico a través de los eufemismos "obra", "acción» o "actuación" de España en Marruecos, sin olvidar expresiones más controvertidas como «labor civilizadora» mientras que, para las operaciones militares de conquista, dominio y sometimiento del territorio y de su población, las fórmulas más habituales fueron "campañas de Marruecos», "campaña de pacificación» o "penetración pacífica " ${ }^{5}$. Muchas de ellas van a estar presentes en las crónicas árabes de Abdelkrim.

Con los albores del nuevo siglo, el continente africano volvió a utilizarse como revulsivo. De esta forma, los dos partidos de la Restauración, conservadores y liberales, confluyeron en reivindicar los «derechos históricos» sobre Marruecos a través de diferentes discursos y estrategias, pero con una idéntica y doble finalidad: compensar el desastre colonial americano y garantizar una discreta presencia en el escenario internacional ${ }^{6}$. Todo ello siempre y cuando no se interfiriese en los planes que las dos grandes potencias del momento, Francia y Gran Bretaña, habían dispuesto para la región ${ }^{7}$.

En esta coyuntura de continua supeditación a los dictados franco-británicos, la solución al reparto de Marruecos, también denominado "problema" o "cuestión marroquí", se fue fraguando con la celebración de conferencias internacionales y a través de una compleja serie de tratados bilaterales. Inmersos en este proceso,

3. Debido a que el texto no está destinado a un lector versado en lengua árabe, se ha empleado la forma más comúnmente usada en castellano para topónimos y nombres propios. El uso de la transliteración, que sigue el modelo de la revista Miscelánea de Estudios Árabes y Hebraicos, se limita a las referencias bibliográficas en dicha lengua.

4. Véase como ejemplo el trabajo de Rodríguez Esteller, Omar: «La intervención española de las aduanas marroquíes (1862-1885)». En Martín Corrales, Eloy (ed.): Marruecos y el colonialismo español (1859-1912). De la Guerra de África a la "penetración pacífica». Barcelona: Bellaterra, 2002, pp. 79-132.

5. Entre los trabajos de referencia para esta cuestión véase GAJATE BAJO, María: «Las campañas de Marruecos y la opinión pública. Una puesta al día", Hispania: Revista española de historia, 79, 263, 2019, pp. 727-756; Iglesias Amorín, Alfonso, «La evolución de la imagen de las guerras de Marruecos y su difusión en la opinión pública (1859-1927)», Revista Universitaria de Historia Militar, 8, 16, pp. 104-131; Iglesias Amorín, Alfonso e Iglesias Iglesias, Noelia: "La presencia de las guerras de Marruecos en el teatro español (1859-1930)", Hispanic Research Journal: Iberian and Latin American Studies, 18, 2, 2017, pp. 131-145; Romero Morales, Yasmina: "Prensa y literatura en la Guerra de África (1859-1860). Opinión publicada, patriotismo y xenofobia", Historia contemporánea, 49, 2014, pp. 619-644.

6. Rubio, Javier: «La crisis finisecular exterior de España: del Mediterráneo (1887) al Mediterráneo (1907)». En De la Torre Gómez, Hipólito y Jiménez Redondo, Juan Carlos (coords.): Portugal y España en la crisis de entresiglos (1890-1918). Madrid: UNED, 2000, pp. 171-202.

7. Para un análisis pormenorizado de la evolución de la posición española en el contexto internacional de la época consúltese Morales Lezcano, Víctor: España, de pequeña potencia a potencia media. Madrid: UNED, 1991. 
los representantes españoles mantuvieron una serie de negociaciones con sus homólogos franceses que se concretaron en 1902 en una propuesta de tratado non nato cuyos términos resultarían, a la postre, mucho más ventajosos que los que finalmente se acordaron ${ }^{8}$. La falta de visión política española, incapaz de concebir que las dos grandes potencias europeas conciliaran intereses, como así fue, llevó a rechazar la propuesta francesa. Temerosos de que los británicos ocupasen las islas Canarias o Mallorca, o ampliasen su base gibraltareña, la adopción de semejante decisión reveló de manera evidente la debilidad y el carácter marginal que España tuvo en el reparto colonial?.

Entretanto, y con el objetivo de que ningún país tuviera control sobre las dos orillas del Estrecho, la Declaración franco-británica (1904), conocida también como Entente cordiale, impulsó en ese mismo año la firma del Convenio hispano-francés. En virtud de este último se le asignaba a España una zona de influencia (de la que quedaba excluida Tánger y su hinterland) sobre la que podría realizar obras y mejoras administrativas, económicas, militares y financieras, pero sin alterar el statu quo por el que Francia reconocía los derechos de Gran Bretaña en Egipto y ésta, a su vez, la expansión francesa desde el territorio argelino al marroquí10.

Por otra parte, la política expansionista propiciada por Bismarck no había visto colmada sus aspiraciones en el continente africano ni en la Conferencia de Madrid (1880) ni en la de Berlín (1884-1885). Asimismo, los pactos entre España, Francia y Gran Bretaña amenazaban el creciente comercio que Alemania mantenía con el sultanato marroquí. De forma que, con el objetivo de romper la Entente (España no suponía ningún problema para las aspiraciones alemanas), el káiser aprovechó su visita a Tánger, en marzo de 1905.

Allí provocó un incidente diplomático al reivindicar públicamente la independencia del imperio jerifiano y criticar abiertamente la creciente influencia francesa. De esta última se había dado sobrada muestra apenas dos meses antes, cuando una misión diplomática impuso una serie de reformas de gran calado al sultán Muley Abdelaziz ${ }^{11}$. Conocido como primera crisis marroquí, el episodio, que fue concebido como medida de presión, consiguió propiciar una conferencia internacional sobre Marruecos. En consecuencia, Francia decidió reforzar sus posiciones

8. Para entender mejor dichas negociaciones y los términos del acuerdo de 1902 véase PASTOR Garrigues, Francisco Manuel: A las puertas del protectorado. Las negociaciones secretas hispanofrancesas en torno a Marmecos (1901-1904). Sevilla: Servicio de Publicaciones de la Universidad de Sevilla, 2013.

9. Para una perspectiva completa del diseño y ejecución de la política exterior española en estos años consúltese González Velilla, María del Carmen: Orientación general de la política exterior española entre 1898 y 1907: los compromisos internacionales. Tesis Doctoral. Madrid: Universidad Complutense, 1998.

10. Para un estudio comparado entre este convenio de 1904 y el tratado de 1912, véase LóPEzHermoso Vallejo, Estela: "De la declaración y convenio hispano-franceses relativos a Marruecos (1904)», Ab Initio: Revista digital para estudiantes de Historia, 1, 2010, pp. 123-148.

11. LarouI, Abdallah: Marruecos: Islam y nacionalismo. Madrid: Mapfre, 1994, p. 99. 
y consolidar su alianza con España a través de un nuevo acuerdo rubricado ese mismo año ${ }^{12}$.

La Conferencia Internacional de Algeciras (16 enero-7 de abril de 1906) fue concebida por Alemania como oportunidad para tratar de recortar la influencia de Francia y Gran Bretaña en África y ampliar los beneficios alemanes en el reparto del continente ${ }^{13}$. Para los representantes de los demás países participantes (Bélgica, Italia, Países Bajos, imperio austrohúngaro, Rusia, Portugal, Suecia y Estados Unidos), se trataba de obtener las mejores condiciones posibles en el reparto de Marruecos y sus intercambios comerciales. En cambio, para los delegados marroquíes se presentaba como el último intento de limitar el alcance de las injerencias extranjeras ${ }^{14}$. Por su parte, Francia y Gran Bretaña esperaban consolidar lo dispuesto en su acuerdo de 1904, mientras que la anfitriona, España, confiaba en mantener su prestigio internacional a través de lo acordado con la Entente ${ }^{15}$.

A tenor de lo dispuesto en el Acta final de la conferencia, las aspiraciones alemanas se vieron frustradas mientras el bloque franco-británico salió fortalecido al mantenerse el statu quo en el reparto del territorio. Así se colige de dos medidas fundamentales con las que se asestaba un golpe definitivo a la autoridad del Sultán: la creación del Banco del Estado y el cuerpo de policía portuaria ${ }^{16}$. Francia consolidaba su hegemonía en el norte de África mientras los británicos se aseguraban, con la zona internacional de Tánger y la zona de influencia asignada a España, que sus intereses no se verían perjudicados. Sin contemplar una contrapartida para Alemania, la cuestión estaba lejos de resolverse, como se evidenció en la crisis de Agadir.

Además de la explotación de una serie de puertos y de los recursos mineros del territorio asignado, España vio garantizada su integridad territorial por ingleses y franceses un año más tarde mediante los Acuerdos tripartitos de Cartagena (1907), acabando así con los recelos suscitados por la posible intervención

12. Sobre los términos de dicho acuerdo véase De la TORRe DeL Río, Rosario: «Preparando la conferencia de Algeciras: al acuerdo hispano-francés de 1 de septiembre de 1905 sobre Marruecos", Cuadernos de historia contemporánea, extra 1, 2007, pp. 313-320.

13. Sueiro Seonne, Susana: España en el Mediterráneo: Primo de Rivera y la "cuestión marroqui," 1923-1930. Madrid: UNED, 1992, p. 9.

14. Para entender la exigua capacidad de maniobra de la posición marroquí véase KALARJi KARAM, Asaad: "The Moroccan Question As Seen From Morocco", North American Review, 183, 8, 1906, pp. 1041-1046.

15. Para más información sobre la posición e intereses de cada uno de los actores mencionados véase GonzÁlez AlCANTud, José Antonio y MarTín Corrales, Eloy (coords.): La Conferencia de Algeciras en 1906: un banquete colonial. Barcelona: Bellaterra, 2007.

16. Sobre las consecuencias de estas medidas véase el lúcido análisis de CARrasco GonzÁLEz, Antonio M.: El reino olvidado. Cinco siglos de Historia de España en África. Madrid: La Esfera de los Libros, 2012, pp. 92-93. 
británica $^{17}$, pero no con el escaso margen de maniobra de la política exterior española, que continuaría supeditada a las directrices de la Entente ${ }^{18}$.

En cuanto al imperio jerifiano, con los acuerdos de 1904 y lo pactado en Algeciras, España y Francia disponían de sustento jurídico para legitimar su actuación en el territorio, que se articuló fundamentalmente en torno al manido argumento de la necesidad de imponer el orden en la zona. De hecho, tras la Declaración de Cartagena, los acontecimientos se precipitaron. Francia intensificó sus presiones para conseguir que Muley Abdelaziz necesitara su aprobación y cooperación para cualquier actuación de índole económica, política, técnica o militar.

Ese mismo año de 1907, el asesinato el 22 de marzo en Marrakech del médico francés Emile Manchamp por parte de las tropas del Sultán proporcionó la excusa perfecta para intervenir militarmente en el sultanato. Aunque no fue el único episodio que sirvió a dicho propósito, sí consiguió alcanzar una inusitada repercusión internacional $^{19}$, y actuó como principal detonante de los sucesos de Casablanca. Siete días después del asesinato de Manchamp, un destacamento francés cruzaba la frontera argelina y ocupaba la ciudad de Uchda sin encontrar oposición alguna por parte de las tropas de Muley Abdelaziz.

En cuanto a los incidentes de Casablanca, considerados como el pistoletazo de salida de la conquista militar francesa del territorio, se originaron tras la revuelta iniciada por las tribus de la cercana región de la Chauía en protesta por el control francés de la aduana del puerto y por la construcción de un tramo de ferrocarril sobre un cementerio. El levantamiento se había cobrado la vida de un grupo de obreros europeos que trabajaban en unas canteras con destino a las obras del puerto. En respuesta, entre el 5 y el 7 de agosto la fuerza naval francesa acometió una operación de castigo sometiendo Casablanca a intensos bombardeos que se saldaron con un millar de víctimas, la destrucción de la ciudad y el desembarco de $\operatorname{tropas}^{20}$.

17. Para entender la coyuntura que impulsó estos acuerdos y sus efectos en la política mediterránea europea véase Egea Bruno, Pedro María: «Los Acuerdos de Cartagena y el Statu Quo en el Mediterráneo", Cartagena histórica, 22, 2008, pp. 26-37; RosAs LEDEZMA, Enrique: "Las "Declaraciones de Cartagena" (1907): significación en la política exterior de España y repercusiones internacionales", Cuadernos de historia moderna y contemporánea, 2, 1981, pp. 213-230.

18. Como pone de manifiesto el análisis de Ponce MARrero, Francisco Javier: «La política exterior española de 1907 a 1920: entre el regeneracionismo de intenciones y la neutralidad condicionada", Historia contemporánea, 34, 2007, pp. 93-116.

19. Además de presentarse dos como causa directa de la intervención militar francesa en el territorio, justificando a su vez de la respuesta española (Diario de Sesiones las Cortes, Congreso de los Diputados, 65, 1911, p. 1755), y de alcanzar gran eco en la prensa francesa y británica de la época, la noticia también se recogió en otras publicaciones, como el Journal of American Medical Association, 55, 1910, p. 956, que lo tildó de «asesinato cobarde».

20. Clément, Jean-François: "Casablanca 1907: el levantamiento de la Chauía, los desórdenes en la ciudad y la conquista de la llanura". En Feliú, Laura, Mateo Dieste, Josep Lluís e IzQuierdo Brichs, Ferran (eds.): Un siglo de movilización social en Marruecos. Barcelona: Bellaterra, 2019, pp. 89-108. 


\section{ROCÍO VELASCO DE CASTRO \\ MARRUECOS, 1911: EN TORNO A LA CRISIS DE AGADIR Y LAS CRÓNICAS \\ DE ABDELKRIM EN EL TELEGRAMA DEL RIF (MAYO-NOVIEMBRE DE 1911)}

Esta circunstancia, unida a la creciente injerencia francesa en la política y economía del sultanato, abocó a una rebelión interna: la Hafidiyya ${ }^{21}$. De un alcance mucho más profundo que la mera oposición al colonialismo, pues también implicaba una serie de reformas modernizadoras de carácter estructural en el modelo de Estado que incluían un proyecto de Constitución ${ }^{22}$, la Hafidiyya desembocó en un enfrentamiento armado entre los partidarios de Abdelaziz y los de su hermano menor, Abdelhafid, que acabó con la entronización de este último en enero de 1908, si bien no fue reconocido por las cancillerías europeas hasta $1909^{23}$.

En gran medida, su triunfo se debió a que consiguió canalizar la mezcla de frustración y contestación interna existente. Por un lado, un acelerado proceso de pauperización que afectaba a toda la población. Por el otro, la fallida modernización del modelo de Estado y sus instituciones, bien por falta de recursos económicos para su implementación, bien por lo inadecuadas de las medidas adoptadas, bien por el rechazo al cambio mostrado por una elite que no estaba dispuesta a perder sus privilegios.

Uno de los ejemplos más paradigmáticos al respecto fueron las reticencias suscitadas en 1903 por la aprobación del impuesto del tertib junto a otras reformas fiscales ${ }^{24}$. Ante la incapacidad de contar con medios y estructuras eficaces para contener a una cada vez más agresiva injerencia extranjera, la rebelión se alzó como única vía posible. La imperiosa necesidad de detener, o al menos de tratar

21. Burke III, Edmund: "La hafidya (août 1907 - janvier 1908). Enjeu social et luttes populaires», Hesperis-Tamuda, XXXI, 1993, pp. 101-105.

22. Sobre la importancia de este proyecto, pues cabe recordar que la primera constitución marroquí no vio la luz hasta 1962, véase López GARcía, Bernabé y Fernández Suzor, Cecilia: Introducción a los regímenes constitucionales árabes. Madrid: Centro de Estudios Políticos y Constitucionales, 1985, pp. 229-232) y Fernández ParRilla, Gonzalo: La literatura marroquí contemporánea: la novela y la crítica literaria. Cuenca: Ediciones de la Universidad de Castilla-La Mancha, 2006, p. 39, nota 31. Este último recoge que fue publicado por entregas en el semanario tangerino Lisan al-Magrib entre el 11 de octubre y el 1 de noviembre de 1908. El texto comprendía de cuatro partes: la dedicada al estatuto fundamental de la nación, la que regularía la organización interna de lo que definen como Consejo consultivo, la que regiría el sistema de elecciones generales y la que conformaría el código penal marroquí. Por su parte, CAGNe, Jean: Nation et Nationalisme au Maroc. Aux racines de la nation marocaine. Rabat: Dar Nachr al Maarifa, 1988, pp. 410-456, 484 y 536-543, incluye copia de las ediciones originales del periódico, correspondientes a los días 11, 18 y 25 de octubre y 1 de noviembre de 1908. En español, pueden consultarse algunos fragmentos en la obra de AL-FAsI, Alal: Los movimientos de independencia en el Mogreb Árabe. El Cairo: Al Risala, 1948, pp. 117-121.

23. Véase como ejemplo el caso español en Galván Rodríguez, Eduardo: «Debates parlamentarios sobre la gestación del protectorado español en Marruecos (1902-1923)». En Alvarado PlanAs, Javier y Domínguez Nafría, Juan Carlos (dirs.): La Administración del protectorado español en Marruecos. Madrid: Centro de Estudios Políticos y Constitucionales, 2014, p. 54.

24. El impuesto del tertib gravaba la propiedad agrícola y ganadera. Su aplicación, que abolía los privilegios fiscales que hasta entonces detentaban los jerifes y ulemas, generó el rechazo generalizado y uno de los detonantes, junto con la rúbrica del Acta de Algeciras, de la Hafidiyya. Sobre el alcance económico de este impuesto y sus efectos en la sociedad marroquí, véase Alaoui, Muley Abdelhadi: $L e$ Maroc face aux convoitises européennes (1830-1912). Salé: Imprenta Beni Snassen, 2001, pp. 112-113 y BoutAleb, Brahim: «Le tertib comme nazila», Hesperis Tamuda, 39, 1, 2001, pp. 29-62. 
de ralentizar esta dinámica, consiguió que Abdelhafid contara con el apoyo de los principales líderes tribales y religiosos del sultanato. Entre ellos, el jerife Muley Ahmed ibn Muhammad ibn Abdallah al-Raisuni, buena parte de los poderosos notables y caídes de Fez, y el jeque Muhammad Mustafa uld Muhammad Fadel, más conocido como Ma al-Aynayn.

Personalidad de gran prestigio entre los ulemas de Fez y Marrakech por su sólida formación, Ma al-Aynayn fue el iniciador de la dinastía de los «sultanes azules", como es conocida especialmente en la historiografía africana, aunque fue su hijo y sucesor en la lucha anti-colonial, Ahmed al-Hiba, el primero en ser conocido por este sobrenombre. Su apoyo a la Hafidiyya y sus buenas relaciones con los alemanes resultaron decisivas en su labor de contención de las tropas francesas en la frontera con Mauritania ${ }^{25}$. También su estrategia, que combinaba fundamentos de la yihad religiosa con la defensa de una identidad sahariana que no entendía de fronteras impuestas por extranjeros ${ }^{26}$.

La baza alemana, la utilización del factor religioso como elemento legitimador a la par que movilizador de la causa, y la identidad de un movimiento sustentado en un medio tribal con características distintivas a las de otras regiones del territorio, son elementos que volveremos a encontrar a partir de 1921 en la resistencia armada liderada por el rifeño Abdelkrim, así como en la estructura y funcionamiento de la efímera República Confederada de Tribus del Rif (1921-1926). No obstante, y a diferencia del rifeño, Ma al-Aynayn sí apoyó un modelo de Estado-nación descentralizado en torno a un sultán al frente del Majzen ${ }^{27}$.

Volviendo al jerife sahariano, que apoyó la revuelta de la Chauía de 1907 mientras intentaba contener a los contingentes franceses provenientes de la frontera mauritana, en 1909 se vio obligado a replegarse de Smara a Tiznit. Para entonces, la supeditación de Abdelhafid a los dictados franceses era casi completa. Como respuesta, el jeque sahariano se proclamó Sultán en mayo de 1910, pero sus harcas fueron derrotadas por tropas francesas, que desde Tadla partieron hacia Fez. La ocupación de esta última, en 1911, desencadenó la crisis de Agadir.

En cuanto al jerife Raisuni, figura clave para entender, entre otras cuestiones, la actuación española en el norte de Marruecos entre 1900 y 1925, ha sido reivindicado en las últimas décadas por una parte de la historiografía marroquí frente a la imagen simplista de bandolero que se ofrecía de él en la época, y a la que

25. Désiré-Vuillemin, Genevièv M.: “Cheikh Ma El Aïnin et le Maroc, ou l'échec d'un moderne Almoravide», Outre-Mers. Revue d'bistoire, 158, 1958, p. 47.

26. Hames, Constant: «Shaykh Mâl'aynîn et les composantes de l'identitémusulmane dans l'ouest saharien (fin 19e-début 20esiècles)». En Pratiques et stratégies identitaires au Sahara. Rabat: Publications de l'Institut des Etudes Africaines, 2001, pp. 153-190.

27. Sobre esta cuestión consúltese Cagne, Jean: Nation et Nationalisme au Maroc. Aux racines de la nation marocaine. Rabat: Dar Nachr al Maarifa, 1988, pp. 200-217 y 225-234; Laroui, Abdallah: Marruecos: Islam y Nacionalismo. Madrid: Mapfre, 1994, pp. 111-112 y 123; Laroui, Abdallah: Orígenes sociales y culturales del nacionalismo marroqui: 1830-1912. Madrid: Mapfre, 1997, pp. 154 y 414-415. 


\section{ROCÍO VELASCO DE CASTRO}

MARRUECOS, 1911: EN TORNO A LA CRISIS DE AGADIR Y LAS CRÓNICAS

DE ABDELKRIM EN EL TELEGRAMA DEL RIF (MAYO-NOVIEMBRE DE 1911)

España contribuyó enormemente ${ }^{28}$. A nivel interno, mostró un creciente desencuentro con el Majzen (1900-1904) que desembocó en su adhesión a la Hafidiyya $(1907-1911)^{29}$

Su importancia para la estabilidad de la zona noroccidental fue reconocida tanto por los españoles como por el sultán Abdelaziz, quien aprobó su designación como gobernador de Yebala (1904-1906) ${ }^{30}$. El nombramiento no satisfacía las aspiraciones del jerife sobre Arcila, ciudad con un importante tráfico comercial de la que se autoproclamó bajá en 1906 con el beneplácito del por entonces pretendiente al sultanato Muley Abdelhafid. Durante su gestión de la plaza y su puerto, Raisuni incumplió lo dispuesto en el Acta de Algeciras en lo relativo a derechos y privilegios de los extranjeros, lo que desembocó en enfrentamiento armado contra españoles y franceses, que reaccionaron enviando sus escuadras a Tánger $^{31}$. No fue hasta 1911, y como consecuencia de la crisis de Agadir, cuando las fuerzas españolas llegaron a un acuerdo de mínimos con el jerife y consiguieron recuperar formalmente el control de la ciudad.

Al igual que Ma al-Aynayn y Abdelkrim, Raisuni gozó de las simpatías alemanas $^{32}$. Consciente de que la debilidad española constituía una ventaja al plantearse como mal menor frente a Francia ${ }^{33}$, alternó con gran pragmatismo una serie de alianzas coyunturales (la primera entre 1911 y 1913, la segunda entre 1915 y 1918, y la tercera entre 1922 y 1924) con periodos de confrontación que dieron como

28. Así se colige del corpus recogido por Velasco DE CASTRO, Rocío: «La lucha anti-colonial en el protectorado español según la historiografía marroquí: Raisuni y Abdelkrim», Revista Universitaria de Historia Militar, 8, 16, 2019, pp. 41-60.

29. Sobre las motivaciones ideológicas que llevaron a Raisuni a apoyar la Hafidiyya y sus posteriores críticas a la gestión de Muley Abdelhafid, véase el análisis de IBN 'Azzūz Hakīm, Muhammad: "Al-Awḍāu al-iŷtimā'iya wa-l-siyāsiya fī-l-šamāl al-garbī 'alà 'ahd al-sulțān Mulāy 'Abd al-'Azīz. Mawqif al-šarīf al-Raisūnī min al-tawra al-ḥafị̣iya. Ziyāra al-šarīf al-Raisūnī li-l-sulțān Mulāy 'Abd al-Hafīz bi-Fās”. En IBN 'Azzūz ḤAKīm, Muḥammad (ed.): Nadwa 'alamīya ḥawla al-šarîf al-Raysūnī wa-l-muqāwama al-maslaḥa fì šamāl al-garbī (1913-1924). Rabat: Mìtāq al-Magrib, 1995, pp. 36-43.

30. Tessainer y TOMAsich, Federico: «Los últimos años de la independencia marroquí: El-Raisuni, gobernador de Tánger y el Fahs (1904-1906)", Awrāq, 14, 1993, pp. 105-123.

31. Quintana Martínez, Eduardo: La marina de guerra española en Africa: Crónica de la campaña del Rif. Madrid: M. A. Rodríguez, 1910, p. 40.

32. Como señala Ortega, Manuel L.: España en Marruecos: el Raisuni. Madrid: Tipografía Moderna, 1917, p. 247, cualquier elemento interno que pudiera entorpecer la acción de Francia en el territorio era considerado como un potencial aliado de Alemania. En esta misma línea, LA PorTe, Pablo: La atracción del imán: el desastre de Annual y sus repercusiones en la política europea, 1921-1923. Madrid: Biblioteca Nueva, 2001, p. 60, sitúa los primeros contactos antes del estallido de la primera guerra mundial.

33. AyaChe, Germain: La guerre du Rif. París: L'Harmattan, 1997, p. 23; TESSAINER y TOMASICH, Federico: El Raisuni. Aliado y enemigo de España. Málaga: Algazara, 1998, p. 41. En esta misma línea, su oposición al colonialismo francés a través de la baza española es analizada por IBN 'Azzūz HaKīm, Muhạmmad: Mawqif al-šarîf al-Raysūnì min al-isti’mār al-faransī. Tetuán: Dispress, 1981. 
resultado dos campañas militares (la primera entre 1913 y 1915 y la segunda entre 1919 y 1921$)^{34}$.

Lejos de entablar una alianza, Abdelkrim nunca llegó a reconocer a Raisuni como autoridad ni su innegable habilidad, diplomática y militar, mostrada en sus relaciones con los representantes coloniales. También resulta paradójico que, tras haber tenido un papel destacado en la Hafidiyya, Abdelkrim se refiriera a él como «rebelde» al Majzen, haciéndose eco así del calificativo empleado por los medios colonialistas españoles ${ }^{35}$. Pese a que ambos colaboraron con las fuerzas de ocupación, Raisuni no llegó a los extremos del rifeño, quien llegó a solicitar la nacionalidad española en mayo y octubre de $1910^{36}$.

Las loas de este último a la labor civilizadora de España en El Telegrama del Rif y la pertenencia de su familia a los llamados «moros pensionados», o marroquíes subvencionados para que "compraran voluntades" ${ }^{37}$ y difundieran entre sus tribus y clanes las ventajas de colaborar con el colonizador ${ }^{38}$, resultan especialmente relevantes durante el periodo que nos ocupa y marcan una diferencia respecto al proceder del jerife de Yebala, que acabó muriendo, en 1925, como prisionero del rifeño.

Al tiempo que Raisuni trataba de extender su influencia en Yebala, en el Rif, Yilali b. Muhammad al-Yussufi al-Zarhuni, más conocido como El Rogui o Bu Hama$\mathrm{ra}^{39}$, había promovido el asentamiento de empresas extranjeras mediante concesiones para la explotación de las minas existentes en la zona oriental ${ }^{40}$. Esta circunstan-

34. Para más información sobre el desarrollo y las consecuencias de estas campañas consúltese IBN 'Azzūz ḤAkīm, Muḥammad: "Mawqif al-šarīf al-Raisūnī min al-Ḥimāya al-mafrūọa 'alà al-Magrib. Al-šarīf al-Raisūnī yu'linu al-ḥarb 'alà Isbāniya. Al-ŷihād fī sabīl Allah difā'an 'an ḥawza al-waṭan. Al-šarīf al-Raisūnī yaltahiqqu bi-ribāt Dār Ibn Qarrī̌s’. En IBN 'AzzŪz ḤAīM, Muḥammad (ed.): Nadwa 'alamīya hawla al- šarīf al-Raysūnì wa-l-muqãwama al-maslaha fì šamāl al-garbì (1913-1924). Rabat: Mītāq alMagrib, 1995 , pp. 51-72.

35. Madariaga, María Rosa de: Abd el-Krim el Jatabi. La lucha por la independencia. Madrid: Alianza, 2009, p. 407. Nótese que, en el fragmento citado, el rifeño emplea los mismos argumentos y expresiones que serán difundidas por la prensa y las publicaciones colonialistas durante varias décadas. Véase como ejemplo García Figueras, Tomás: La acción africana de España en torno al 98, 1860-1912. De la crisis de la política africana, 1898, al protectorado de Marruecos, 1912. Madrid, csic, 1966, p. 289.

36. Véanse los documentos 38, 41 y 42 que recoge Gómez MarTínez, Juan Antonio: Mohammed ben Abd el-Krim el-Jattaby el-Aydiri el-Urriagly según documentos oficiales españoles (basta 1914). Lorca: Editorial Fajardo el Bravo, 2008, pp. 186-188 y 194-198.

37. La familia de Abdelkrim, como tantas otras, habría formado parte de la red de corrupción en torno al protectorado español descrita por MADARIAGA, María Rosa de: «El lucrativo «negocio" del protectorado español", Hispania Nova, 16, p. 592. DOI: https://doi.org/10.20318/hn.2018.4049.

38. Como señala Madariaga, María Rosa de: Abd el-Krim el Jatabi. La lucha por la independencia. Madrid: Alianza, 2009, pp. 63-64, el clan de los Jattabi tuvo que hacer frente una multa impuesta por los responsables de su propia cabila por su condición de colaborador con los españoles.

39. Para más detalles de su trayectoria véase Maldonado, Eduardo: El Rogui. Madrid: Instituto General Franco, 1950.

40. Como señala Seco Serrano, Carlos: La España de Alfonso XIII: el estado, la política, los movimientos sociales. Madrid: Espasa Calpe, 2002, p. 266, fueron dos las compañías adjudicatarias de los derechos de explotación de los yacimientos de Beni Bu Ifrur. La Norte-Africana, que estaba constituida 


\section{ROCÍO VELASCO DE CASTRO}

MARRUECOS, 1911: EN TORNO A LA CRISIS DE AGADIR Y LAS CRÓNICAS

DE ABDELKRIM EN EL TELEGRAMA DEL RIF (MAYO-NOVIEMBRE DE 1911)

cia, unida a la ocupación española de La Restinga y Cabo de Agua, ambas en 1908, se tradujo en un levantamiento generalizado de las cabilas que desembocó en el ataque a un grupo de trabajadores españoles que operaban en las minas de Beni $\mathrm{Bu}$ Ifrur $^{41}$. El jefe de dicha cabila era Muhammad Amizzián o Mizzián quien, además de erigirse como el principal opositor de la política pro-occidental de Bu Hamara hasta su derrota y abandono definitivo del Rif, lideró la rebelión contraria a la reanudación de los trabajos de acondicionamiento para la explotación de las minas. De forma que, a partir de 1908, las agresiones contra los intereses españoles se hicieron frecuentes, ocasionando numerosos conflictos con las autoridades militares de Melilla ${ }^{42}$.

En julio de 1909, el ataque a un grupo de operarios que construían en Sidi Musa un puente destinado al futuro ferrocarril minero inició el enfrentamiento armado conocido como campaña de Melilla. Esta se saldó, el 26 de julio, con la derrota de las tropas españolas en el Barranco del Lobo, en las estribaciones del monte Gurugú, de importante valor estratégico. Episodio premonitorio en muchos aspectos de lo que volvería a suceder en Annual ${ }^{43}$ hace ahora justo un siglo, alcanzó continuidad en un nuevo conflicto armado surgido en plena crisis de Agadir: la campaña del Kert o primera guerra del Rif (1911-1912). De esta forma, la apertura simultánea de dos frentes: los de Raisuni en Yebala y Amizzián en el Rif, y más tarde los de Raisuni en el flanco occidental y Abdelkrim en el oriental, constituyó durante un tiempo un serio problema para el ejército español.

Todo ello era en parte consecuencia, por un lado, de la creciente necesidad del gobierno español de reforzar la defensa en torno a sus plazas de soberanía y, por otro, de la voluntad de hacer valer sus derechos en el territorio tras conocerse el contenido del Acuerdo franco-alemán de 1909. En virtud de este convenio, se garantizaba la libertad económica de Alemania en Marruecos mientras Francia conservaba sus privilegios e influencia política en el territorio ${ }^{44}$. Si bien el texto

en sus dos terceras partes por franceses, y la Española de las Minas del Rif, íntegramente nacional. Sobre la pugna entre ambas compañías véase Escudero, Antonio: "Las minas de Guelaya y la Guerra del Rif», Pasado y Memoria. Revista de Historia Contemporánea, 13, 2014, pp. 332-335.

41. Villalobos, Federico: El sueño colonial: las guerras de España en Marruecos. Barcelona: Ariel, 2004, p. 79. Para más información sobre los detonantes y consecuencias del incidente véase MADARIAGA, María Rosa de: España y el Rif. Crónica de una historia casi olvidada. Melilla: unED, 1999, pp. 133-157.

42. Para más información sobre su trayectoria véase IBN 'Azzūz Hakīm, Muhammad: Le cherif Ameziane. Rabat: Le Mémorial du Maroc, V, 1983 y el reciente trabajo de Yechouti, Rachid: "La sedición del jerife Mohamed Ameziane en el Rif, 1909-1912». En Feliú, Laura, Mateo Dieste, Josep Lluís e IzQuierdo Brichs, Ferran (eds.): Un siglo de movilización social en Marruecos. Barcelona: Bellaterra, 2019, pp. 109-126.

43. Sobre esta comparativa véanse algunos de los factores señalados por LA PorTe, Pablo: $E l$ Desastre de Annual y la crisis de la Restauración en España (1921-1923). Tesis doctoral. Universidad Complutense de Madrid, 1997, pp. 78-92.

44. Sobre los detalles de este acuerdo consúltese Edwards, E. W.: «The Franco-German Agreement on Morocco, 1909", The English Historical Review, 78, 308, 1963, pp. 483-513. DOI: https://doi. org/10.1093/ehr/LXXVIII.CCCVIII.483 
conseguía limar asperezas entre las dos potencias, para España supuso la constatación de su débil posición.

Como respuesta, se optó por redoblar los esfuerzos en dos líneas de actuación que ya desde 1907 se habían puesto en marcha: mientras en la prensa nacional se publicaban una serie de denuncias contra Francia por el incumplimiento de varios articulados del Acta de Algeciras, en el territorio, la creciente rivalidad francoespañola se canalizaba en una "indisimulada carrera» ${ }^{45}$ en torno a la ocupación de nuevas posiciones ${ }^{46}$. En abril de 1911, un nuevo movimiento expansionista de Francia desencadenó la respuesta alemana y con ello, el estallido de la segunda crisis marroquí o crisis de Agadir. Para entonces, destacamentos españoles habían entrado por Ceuta en dirección a Tetuán mientras continuaban las maniobras de expansión desde Melilla.

\section{LA CRISIS DE AGADIR ${ }^{47}$ (21 DE MAYO-4 DE NOVIEMBRE DE 1911)}

Aunque su inicio suele situarse en la ocupación francesa de Fez, el 21 de mayo de 1911, lo cierto es que su génesis se remontaría a finales del mes de abril, cuando, con el pretexto de proteger vidas y propiedades europeas, los franceses enviaron tropas a la capital del sultanato para sofocar una revuelta contra Muley Abdelhafid con el auténtico propósito de ocupar militarmente la ciudad. Desde allí comenzaron a avanzar hasta la zona de influencia española, lo que contravenía lo dispuesto tanto en el acuerdo de 1904 como en el Acta de Algeciras.

La maniobra, que incluía el fomento de las revueltas contra el Sultán, ya se había acometido con éxito en Túnez con motivo de la «insurrección de la mechba" (1894-1895), un levantamiento provocado por el establecimiento de un nuevo impuesto de capitación (yizya en árabe clásico ${ }^{48}$ con el que se duplicarían los ingresos del bey otomano ${ }^{49}$. Reprimida por franceses y británicos, no fue la última, pero sí la más relevante porque vino acompañada de un acelerado proceso de endeudamiento que supuso el punto de inflexión para la ocupación militar francesa

45. Expresión empleada en el magnífico análisis de las relaciones hispano-francesas y su reflejo en la prensa de la época por GAJATE BAjO, María: El impacto de la Guerra de Marruecos en Salamanca (1906-1925). Tesis Doctoral. Universidad de Salamanca, 2011, p. 216.

46. Véase al respecto MATEO Dieste, Josep Lluís: La "hermandad" hispano-marroquí: política y religión bajo el Protectorado español en Marruecos (1912-1956). Barcelona: Bellaterra, 2003, p. 58.

47. Para un estudio pormenorizado de la crisis y su incidencia internacional sigue siendo un referente la obra de Allain, Jean-Claude: Agadir 1911. Une Crise impérialiste en Europe pour la conquête du Maroc. París: Université Paris I La Sorbonne,1976.

48. Sobre el origen y repercusiones de este impuesto, véase la definición de Maíllo SALGADO, Felipe: Vocabulario de historia árabe e islámica. Madrid: Akal, 1996, pp. 265-266.

49. Pese a su antigüedad, sigue teniendo vigencia el trabajo de SLAMA, Bice: L'insurrection de 1864 en Tunisie. Túnez: Maison tunisienne de l'Édition, 1967. 


\section{ROCÍO VELASCO DE CASTRO}

MARRUECOS, 1911: EN TORNO A LA CRISIS DE AGADIR Y LAS CRÓNICAS

DE ABDELKRIM EN EL TELEGRAMA DEL RIF (MAYO-NOVIEMBRE DE 1911)

y el establecimiento del protectorado, en $1881^{50}$. El paralelismo con el caso marroquí, desde la imposición del impuesto del tertib (1903), pasando por la Hafidiyya (1906) hasta esta nueva revuelta (1911) y la firma del tratado franco-marroquí por el que se instauraba el protectorado (1912), resulta más que palmario.

Desde mediados de marzo de 1911, algunas de las cabilas cercanas a Fez se levantaron contra el Sultán y mantuvieron cercada la plaza hasta que las tropas francesas consiguieron levantar el bloqueo, el 27 de abril, como parte de la estrategia que concluyó apenas un mes después con la ocupación militar de la ciudad. Paralelamente, el avance francés había provocado otro levantamiento protagonizado en esta ocasión por el príncipe Muley al-Zayn b. al-Hassan, hermano de Abdelhafid, quien a principios del mes de abril de 1911 recibió el juramento de fidelidad de los habitantes de Mequinez. De esta forma, los franceses justificaron sendas actuaciones en defensa del legítimo Sultán al acudir a la llamada de auxilio de Muley Abdelhafid y acabaron con las dos revueltas, además de ocupar Fez y Mequinez ${ }^{51}$.

Ya fuera mediante la fuerza o a través de la petición del soberano de turno, el hecho incontestable era que la presencia francesa y su dominio militar del territorio seguían el curso previsto. La caída de Fez, además de una gran carga simbólica, concienció a las cancillerías europeas, espacialmente la alemana, la británica y la española, de que las ambiciones francesas y su empeño en precipitar los acontecimientos obedecían a intereses que iban más allá de lo pactado en Algeciras.

Así, en su avance hacia Fez, y con el pretexto de reclutar una mehala destinada a luchar contra la citada revuelta que cercaba a Muley Abdelhafid, las tropas francesas se situaron en las proximidades de Alcazarquivir con intención de entrar en la ciudad que, según el acuerdo franco-español de 1904, quedaba ubicada bajo la zona de influencia española ${ }^{52}$. El gobierno de Canalejas interpretó el gesto como un ataque a los intereses nacionales, al que se decidió responder, siguiendo la dinámica francesa, con la ocupación militar de Larache (8 de junio) y Alcazarquivir (11 de junio).

Para entonces, no solo preocupaba el expansionismo impulsado desde París, también la acometividad de Tazia al-Bakkar, quien en su guerra abierta contra el Majzen, lideraba desde su cabila natal de Beni Aros un levantamiento de toda Yebala. El asesinato del protegido español Ahmed b. al-Malik y de sus hijos, unido al

50. Para una visión más completa de este proceso véase el clásico de CANIAGe, Jean: Les origines du Protectorat français en Tunisie, 1861-1881. Túnez: Maison tunisienne de l'édition, 1968.

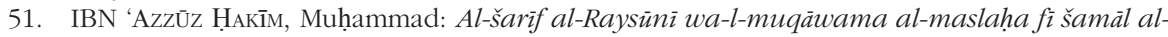
Magrib. Rabat: al-Sāhill, 1981, p. 16.

52. Calvo, Gonzalo: España en Marruecos (1910-1913): acción de España en las regiones de Larache, Alcázar, Ceuta y Melilla, con el relato de la campaña del Rif en 1911-1912. Barcelona: Maucci, 1913, p. 263, relata las conversaciones entre los capitanes Moreaux y Ovilo tras la llegada de los franceses a las inmediaciones de Larache. 
asalto del zoco de Alcazarquivir a principios de junio, aconsejaban una respuesta expeditiva ${ }^{53}$.

Una vez más, Raisuni entendió la alianza coyuntural con España y su influencia en la zona como medio más efectivo para evitar el envite francés y también el éxito de al-Bakkar, por lo que facilitó el agrupamiento de las fuerzas españolas y su avance hacia Alcazarquivir y Arcila ${ }^{54}$. Así, el desembarco y ocupación de Larache se realizó pacíficamente gracias al buen entendimiento entre el jerife y el cónsul español en la plaza, Juan Zugasti, a lo que también contribuyó el talante del capitán Ovilo, muy diferente del exhibido poco después por el controvertido Fernández Silvestre ${ }^{55}$. Ovilo estaba al mando del tabor de policía indígena que operaba en la ciudad y fue el responsable de dirigirlas, junto a algunos soldados de Infantería de Marina recién desembarcados, hacia Alcazarquivir ${ }^{56}$.

Si bien la maniobra española reforzó su posición, no consiguió acabar con alBakkar, al que Raisuni tuvo que hacer frente ${ }^{57}$. Tampoco disuadió a los franceses, que continuaban interesados en hacerse con Alcazarquivir, si bien las tensiones acabaron diluyéndose ante la aparición en escena de Alemania. A esto se sumó el hecho de que la llegada de Fernández Silvestre a la plaza, el 17 de junio de 1911, dificultó las relaciones con el Raisuni quien, a su vez, trataba de obstaculizar tanto a franceses como a españoles en su pugna por el control de la ciudad ${ }^{58}$. En este complejo entramado político y militar, el creciente antagonismo entre ambos personajes comenzó a manifestarse a finales de agosto, y pese a que posteriormente ambos lograron encauzar las relaciones de manera puntual, el creciente

53. Tessainer y Tomasich, Federico: El Raisuni. Aliado y enemigo de España. Málaga: Algazara, 1998, p. 97.

54. BARCeló, Ricardo: "La actitud del Cherif Mulay Ahmed Raisuni ante el desembarco español en Larache y la toma de Alcazarquivir en 1911", Revista de Estudios Africanos, X, 18-19, 1996, pp. 101-107.

55. Tessainer y Tomasich, Federico: El Raisuni. Aliado y enemigo de España. Málaga: Algazara, 1998, pp. 100-101. Para una semblanza crítica del personaje y de su labor en Marruecos véase el análisis de Gajate Bajo, María: "Manuel Fernández Silvestre: luces y sombras de un militar muy novelesco». En Asociación Española de Historia Militar (ed.): Novela histórica e historia militar. Actas del II Congreso Internacional de Historia Militar. Universidad de La Rioja, 27-29 de mayo de 2015. Madrid: Ministerio de Defensa, 2016, pp. 377-400.

56. García Figueras, Tomás: La acción africana de España en torno al 98, 1860-1912. Madrid: CSIC, 1966, p. 377; OrtegA, Manuel L.: España en Marruecos: el Raisuni. Madrid: Tipografía Moderna, 1917, p. xxi.

57. KhallūQ Timsamānī, 'Abd al-'Azīz: País Yebala: Majzen, España y Abmed Raisuni. Granada: Editorial Universidad de Granada, 1999, p. 97.

58. Sobre este difícil equilibrio véase la información que aporta IBN 'Azzūz ḤAkīm, Muhammad: Al-šarīf al-Raysūnì wa-l-muqāwama al-maslaha fī šamāl al-Magrib. Rabat: al-Sāhill, 1981. A propósito de la habilidad del jerife en gestionar la debilidad española, es señalada, entre otros por KHALLŪQ TimsamĀñ̄, 'Abd al-'Azīz: País Yebala: Majzen, España y Abmed Raisuni. Granada: Editorial Universidad de Granada, 1999, p. 81 y Martín, Miguel: El colonialismo español en Marruecos, 1850-1956. París: Ruedo Ibérico, 1973, p. 49. 
desencuentro desembocó en el enfrentamiento directo que condujo inexorablemente a la campaña de $1913^{59}$.

Al mismo tiempo que la situación en Yebala distaba mucho de ser estable, en el Rif, la reanudación de los trabajos de acondicionamiento para las explotaciones mineras tras el desastre militar en el Barranco del Lobo volvió a generar conflicto con las tribus aledañas a Melilla. En el verano de 1911, un nuevo ataque al personal militar que realizaba estudios topográficos cerca del río Kert con el objetivo de extender el avance español actuó como detonante de la campaña del Kert o primera guerra del Rif (24 de agosto de $1911-15$ de mayo de 1912) ${ }^{60}$. Liderada por Amizzián, quien murió en la contienda, supuso a priori la consolidación de la ocupación española en numerosas posiciones del Rif oriental. Su sucesor al frente de la rebelión rifeña, Abdelkrim, demostraría lo engañoso de esta afirmación al constatarse en Annual la reiteración de los errores que habían llevado a la derrota de 1909 .

La entrada en Fez de las tropas francesas hizo saltar las alarmas en Alemania, que seguía sin ver satisfechas sus ambiciones coloniales. La política ofensiva gala fue respondida con idéntica vehemencia. Si los franceses se hacían con la capital, el 21 de mayo, el 1 de julio, y con el pretexto de defender a los comerciantes alemanes de la zona, el káiser ordenaba fondear el cañonero Panther en las proximidades del puerto de Agadir como medida de presión. Se repetía así el modus operandi de 1905. Poco después, el 5 de julio, el pequeño cañonero fue sustituido por el crucero Berlín. Este reemplazo, unido a un silencio diplomático de veinte días ante el desconcierto de no pocas cancillerías europeas, indicaba que se trataba de un pulso en firme.

Agadir era un enclave estratégico de gran importancia en la costa atlántica, tanto por constituir el mejor puerto en la región situada entre Gibraltar y Canarias, como por la situación que ocupaba dentro del protectorado francés. Y si bien era cierto que Alemania no ambicionaba formar parte del reparto del territorio marroquí, sí que pretendía salvaguardar sus intereses comerciales y los de sus nacionales, además de utilizar el incidente para exigir mayores contrapartidas en el continente de las obtenidas hasta el momento. En este contexto entraron en juego los territorios franceses en Camerún y el Congo junto a los hermanos Mannesmann, cuyos intereses en la explotación de las minas del Rif, entre otros negocios

59. Para la evolución de la relación entre ambos entre 1911 y 1912 véase Tessainer y Tomasich, Federico: El Raisuni. Aliado y enemigo de España. Málaga: Algazara, 1998, pp. 101-110.

60. Para una panorámica completa de estas campañas véase MADARIAGA, María Rosa de: En el Barranco del Lobo: las guerras de Marruecos. Madrid: Alianza, 2005 y Villalobos, Federico: El sueño colonial: las guerras de España en Marruecos. Barcelona: Ariel, 2004. Para una visión más exhaustiva sobre las operaciones militares en el periodo que nos ocupa consúltese SERVICIO HISTÓRICO MILITAR: Historia de las campañas de Marruecos, II: Campaña del Rif de 1909. Campaña del Kert (19111912) y acción militar y política posterior en el territorio de Melilla (1912-1919). Campañas de Yebala (1913-1919). Madrid: Imprenta del Servicio Geográfico del Ejército, 1951. 
que establecieron y mantuvieron en Marruecos, los llevó a estrechar desde 1913 relaciones con Abdelkrim ${ }^{61}$.

Por su parte, el gobierno británico trató de disuadir a su socio al considerar precipitada y de graves repercusiones la operación, como así fue. Con los acuerdos de la Entente cordiale sobre la mesa, el estudio de la maniobra alemana se centró en averiguar sus posibles consecuencias en los intereses comerciales y el tráfico marítimo británico. Con el temor de si el objetivo era convertir Agadir en una base naval alemana en el Atlántico, la base que la Royal Navy tenía en Gibraltar se movilizó ante una posible entrada en guerra. Como señalaba Winston Churchill en su análisis de la crisis, el silencio diplomático alemán, que hasta el 21 de julio no emitió comunicado alguno, tampoco ayudó a distender el ambiente. De eso se trataba, precisamente ${ }^{62}$. Atendiendo a sus compromisos, Gran Bretaña decidió mantener los términos de la Entente y con ello reforzar la posición francesa ante la presión alemana.

Inmersos en esta dinámica, con una España combatiendo a Amizzián en el Rif, manteniendo un precario equilibrio con Raisuni en Yebala y tratando de hacer frente a las ambiciones francesas en el territorio asignado a su control e influencia, comenzaron las conversaciones franco-alemanas. Las negociaciones culminaron oficialmente el 4 de noviembre de 1911, fecha de la firma del tratado bilateral con el que se dio fin no solo a la crisis de Agadir. También y sobre todo, a las presiones alemanas que obstaculizaban la implantación del protectorado en Marruecos.

En virtud del acuerdo, Alemania renunciaba a cualquier reivindicación territorial al reconocer que su interés en Marruecos era exclusivamente económico (art. I); aceptaba la posición hegemónica de Francia en Marruecos al reconocer las esferas de influencia francesas y españolas en el territorio y el derecho de Francia a continuar con las operaciones militares tendentes a la ocupación y dominio del sultanato (art. II); y veía garantizados sus intereses económicos, especialmente los derivados de las extracciones mineras (arts. V-VII). Como contrapartida, recibió de Francia una parte del Congo francés que tuviera salida al mar y una franja de territorio del actual Camerún que pasó a denominarse Nuevo Camerún ${ }^{63}$.

Eliminados los impedimentos, Muley Abdelhafid se vio abocado a rubricar el 30 de marzo de 1912 el tratado franco-marroquí por el que implantaba un régimen colonial en el territorio. En disconformidad con sus contenidos, que entregaban

61. Rivet, Daniel: "Mines et politique au Maroc, 1907-1914 (D'après les Archives du Quai d'Orsay)", Revue d'Histoire Moderne E Contemporaine, 26, 4, 1979, pp. 549-578. Sobre los primeros contactos con el rifeño de los que en la documentación española se tiene constancia, véanse los informes fechados el 19 de marzo y el 9 de mayo de 1913 (documentos 95 y 101) recogidos por Gómez MarTínez, Juan Antonio: Mohammed ben Abd el-Krim el-Jattaby el-Aydiri el-Urriagly según documentos oficiales españoles (hasta 1914). Lorca: Editorial Fajardo el Bravo, 2008, pp. 341-343 y 361-362.

62. Churchil, Winston: The World Crisis, 1911-1918. Londres: Simon and Shuster, 2005, pp. 26-47.

63. Las reivindicaciones alemanas sobre el Congo francés ya se habían planteado en las primeras negociaciones con los representantes franceses, como muestra el trabajo de Wavarovsky, Frances M.: German Policy in the Agadir Crisis of 1911. Tesis Doctoral. Stanford: Stanford University, 1939, pp. 73-85. 


\section{ROCÍO VELASCO DE CASTRO \\ MARRUECOS, 1911: EN TORNO A LA CRISIS DE AGADIR Y LAS CRÓNICAS \\ DE ABDELKRIM EN EL TELEGRAMA DEL RIF (MAYO-NOVIEMBRE DE 1911)}

el sultanato a Francia manteniéndose la ficción de un gobierno indígena ${ }^{64}$ títere, abdicó en su hermano, Muley Yussuf, quien tuvo que hacer frente a la división del otrora imperio jerifiano en tres administraciones diferentes: la francesa, la española (con dos zonas de influencia, una al norte y otra al sur de la francesa), y la internacional de Tánger y su binterland, cuyo estatuto no quedó establecido hasta 1923. Respecto a las condiciones y términos en los que España se hizo cargo de su zona de influencia, quedaron establecidos en el acuerdo franco-español de 27 de noviembre de 1912 .

A nivel internacional, la crisis de Agadir constituyó la antesala de la primera guerra mundial. Lejos de suavizar tensiones, agudizó el desencuentro entre el país germano y fortaleció entente franco-británica. Entre otras cuestiones, Agadir impulsó el acuerdo naval de 23 de julio de 1912 por el cual la Royal Navy prometía proteger la costa norte de Francia del ataque alemán, mientras Francia concentraba su flota en el Mediterráneo occidental y se comprometía a defender allí los intereses británicos. Francia pudo así proteger sus comunicaciones con sus colonias del norte de África y Gran Bretaña concentrar sus efectivos en sus aguas nacionales para oponerse a la flota alemana ${ }^{65}$.

\section{ABDELKRIM Y EL TELEGRAMA DEL RIF 60}

Como se desprende del proceso de gestación y evolución del medio, El Telegrama del Rif nacía en Melilla en 1902 no muy lejos de la Comandancia Militar, donde fue destinado su fundador y director, Cándido Lobera, con un objetivo muy definido ${ }^{67}$. Al igual que años más tarde sucederá con África. Revista de Tropas Coloniales (1924-1936), se trataba de dar una voz a los defensores de la acción colonial española, y muy especialmente de la labor desempeñada por los militares desplegados en el territorio, primero para tomar parte en las campañas de ocupación y control del territorio y posteriormente para gestionar las instituciones coloniales ${ }^{68}$.

64. Se emplea (y se reivindica) el término "indígena" porque es el que aparece en la documentación de la época y porque se usa, siguiendo la definición del Diccionario de la lengua española (actualización de 2020), sin la carga peyorativa atribuida en los actuales estudios descolonizadores (evítese el anglicismo decolonial, que no está recogido en dicho Diccionario).

65. Sobre las negociaciones previas a este acuerdo y sus interpretaciones posteriores en los albores de la contienda mundial véase HeAley, Gordon D.: The Anglo-French Military and Naval conversations, 1906-1912: A study in pre-war Diplomacy. Austin: Texas University, 1952, pp. 106-130.

66. Se trata de una primera aproximación, como consta en el título del trabajo, que alcanzará continuidad y una mayor profundidad de análisis en posteriores publicaciones.

67. Gallego Aranda, Salvador y Marqués Leiva, María Rosa: Cándido Lobera Girela. Militar, periodista, político y escritor (1871-1932). Granada: Atrio, 2014, pp. 153-223.

68. Para una introducción al alcance y significación de ambos medios en la propaganda colonial véase VELASCO DE CASTRO, Rocío: «La prensa militar africanista. El Telegrama del Rif y la Revista de Tropas Coloniales». En Viñas Martín, Ángel y Puell de la Villa, Fernando (coords.): La historia militar hoy: investigaciones y tendencias. Madrid: UNED, 2015, pp. 225-246. 
Pese a las diferencias existentes en su tipología, formato y contenidos, la interacción de parte de la plantilla y colaboradores de ambos medios, con el propio Lobera como mejor exponente, escenificaba una confluencia a la que contribuía la estrecha vinculación de sus miembros con el Ejército. De hecho, el ideario militar africanista expresado en la revista se veía perfectamente reflejado en los editoriales del periódico y ambos llegaron a retroalimentarse en no pocos aspectos ${ }^{69}$.

Junto a la necesidad de defender la penetración militar, los objetivos prioritarios de la labor civilizadora debían pasar por la implementación de la explotación del agro marroquí, los recursos mineros del Rif y el tráfico comercial con la metrópoli. La labor cultural y educativa, presente siempre con mayor asiduidad y profundidad de tratamiento en la revista que en el periódico, ocupaba también un espacio que, en el caso de El Telegrama, adquiría un carácter local o regional con la idiosincrasia rifeña como principal protagonista. De ahí la pertinencia de que fuese precisamente un rifeño como Abdelkrim el encargado de trasmitir las bondades de la hermandad hispano-rifeña, no tanto hispano-árabe o hispano-marroquí.

En cuanto a la vinculación de Abdelkrim con El Telegrama del Rif, se explica por la relación del rifeño con su fundador y director, Cándido Lobera, al que conoció en uno de los viajes de su padre a Melilla, al que solía acompañar. De hecho, según se recoge en la biografía de Lobera, en la recopilación de la documentación oficial española sobre Abdelkrim y en la biografía de este último, fue el patriarca quien trató de mover sus contactos para encontrarle a su hijo un empleo en la plaza. Miembro del "Partido español», como se ha comentado en páginas anteriores, sus dos hijos se beneficiaron de los privilegios y contactos destinados a premiar a los colaboradores con la empresa colonial española. De este modo logró el puesto de profesor auxiliar de la escuela hispano-árabe de primera enseñanza para niños musulmanes en Melilla ${ }^{70}$. Abdelkrim compaginó esta labor con su incursión en el periodismo. Así, en 1906 y a petición de Lobera, el rifeño fue invitado a prestar su colaboración en el medio como redactor retribuido mediante la publicación de una serie de crónicas en árabe.

La primera cuestión que convendría dilucidar es la autoría de los textos. Si se asume, como así parece, que el rifeño sería el responsable de la totalidad del corpus publicado en árabe, convendría hacer algunas matizaciones sobre lo publicado al respecto. En su biografía sobre Abdelkrim, Madariaga sitúa la primera crónica de Abdelkrim en marzo de 1907 y la última en abril de 1915 ${ }^{71}$. Sin embargo, la primera crónica en árabe que consta como tal bajo el epígrafe «Sección árabe» data del sábado 29 de septiembre de 1906 y la última se publicó el lunes

69. Sobre dicho ideario véase VELASCO DE CASTRO, Rocío: "De periodistas improvisados a golpistas consumados: el ideario militar africanista de la Revista de Tropas Coloniales (1924-1936)", El Argonauta español, 10, 2013. URL: http://argonauta.revues.org/1590

70. Galván Jiménez, Juan. Apud: Gómez Martínez, Juan Antonio: Mohammed ben Abd el-Krim elJattaby el-Aydiri el-Urriagly según documentos oficiales españoles (hasta 1914). Lorca: Editorial Fajardo el Bravo, 2008, p. 142.

71. Madariaga, María Rosa de: Abd el-Krim el Jatani. La lucha por la independencia. Madrid: Alianza, 2009, pp. 68-69. 


\section{ROCÍO VELASCO DE CASTRO \\ MARRUECOS, 1911: EN TORNO A LA CRISIS DE AGADIR Y LAS CRÓNICAS \\ DE ABDELKRIM EN EL TELEGRAMA DEL RIF (MAYO-NOVIEMBRE DE 1911)}

26 de abril de 1915. No obstante, el 31 de marzo de 1906 se editaba un número especial bilingüe con motivo del enlace de Alfonso XIII con Victoria Eugenia de Battenberg. Asimismo, los días 23 y 25 de septiembre aparecían unas breves notas en árabe dedicadas a la retirada del explorador y topógrafo francés Gabriel Delbrel del territorio comandado por Bu Hamara tras haber sido uno de sus más estrechos colaboradores.

En un detallado análisis de la trayectoria de Cándido Lobera, en el que se incluyen las principales características de forma y contenido de las ediciones de El Telegrama del Rif, se confirma lo hallado en el vaciado de ejemplares. Sobre la edición de 1906, se dice que a partir del 16 de septiembre apareció también la fecha en árabe siguiendo el calendario musulmán y que el 29 de septiembre se insertaba por primera vez la «Sección Árabe», si bien desde días antes habían ido publicándose noticias en este idioma. La aparición de un suplemento mensual no se anunció hasta el mes de noviembre, cuyo primer número vio la luz el día $22^{72}$.

Dicha información tampoco se refleja en la obra de Gómez Martínez. Este último, responsable de una recopilación de documentos oficiales españoles sobre Abdelkrim, no recoge la existencia de textos en árabe en El Telegrama del Rif hasta marzo de $1907^{73}$, acorde con lo expuesto por Madariaga. A tenor del vaciado realizado y de lo expuesto por Woolman y Chtatou, quienes sitúan en 1906 a Abdelkrim ejerciendo su primer trabajo periodístico para el medio (como director del suplemento árabe según Woolman, como editor según Chtatou) ${ }^{74}$, la primera crónica dataría de 1906.

Si consideramos la crónica del 29 de septiembre como la primera, bajo el título "Noticias de Tánger» ${ }^{75}$ tiene al jerife de Yebala, Ahmed al-Raisuni, como protagonista. Su distribución, en la segunda columna de la primera página, resulta de lo más pertinente al encontrarse en paralelo con el editorial en el que se apela al patriotismo de los medios de prensa y se apela a la defensa de la labor de los militares en Marruecos, en clara alusión al rechazo causado en la opinión pública tras conocerse el desastre del Barranco del Lobo (1909) ${ }^{76}$. En cuanto a la última, dispuesta en la sexta columna de la primera página a diferencia de la anterior,

72. Gallego Aranda, Salvador y Marqués Leiva, María Rosa: Cándido Lobera Girela. Militar, periodista, político y escritor (1871-1932). Granada: Atrio, 2014, pp. 168-169.

73. Gómez MarTínez, Juan Antonio: Mohammed ben Abd el-Krim el-Jattaby el-Aydiri el-Urriagly según documentos oficiales españoles (hasta 1914). Lorca: Editorial Fajardo el Bravo, 2008, p. 142.

74. Chtatou, Mohamed: "Aspectos de la organización política en el Rif durante el reinado de Ben Abdel-Krim El-Khattabi», Fundamentos de Antropología, 4-5, 1996, p. 63; Woolman, David S.: Abdel-Krim y la Guerra del Rif. Barcelona: Oikos, 1988, p. 91.

75. Para no sobrecargar el texto con transliteraciones innecesarias se ha optado por traducir directamente al español la información y los títulos de los textos en árabe. Para el lector interesado en su consulta, se ofrecen las referencias completas de cada uno de ellos con objeto de facilitar su búsqueda en la publicación.

76. Como señala Gajate Bajo, María: «Las campañas de Marruecos y la opinión pública. Una puesta al dían, Hispania, LXXIX, 263, 2019, p. 727-756, el episodio del Barranco del Lobo supuso un punto de inflexión en el compromiso de los medios de prensa y de algunos de sus escritores más 
está dedicada a recordar las celebraciones que tuvieron lugar en enero en todo el mundo islámico con motivo de la fiesta del Maulid (mulud en árabe marroquí), o fiesta del nacimiento del Profeta.

Un dato importante a tener en cuenta es que se trata de un numeroso conjunto de crónicas anónimas publicadas en dos formatos: integradas en los contenidos en español bajo el epígrafe "Información Árabe» (que es al que se refieren los autores consultados), y como suplemento en lengua árabe adjunto a la publicación. Buena parte de las que conforman el primer grupo se encuentran dispuestas en la primera o primera y segunda página. Pero también encontramos algunos textos en la segunda o tercera página ${ }^{77}$. No obstante, la periodización y extensión no son homogéneas $^{78}$. En el caso del suplemento, siempre de cuatro páginas (normalmente la última se destina a anuncios publicitarios), tampoco puede establecerse un patrón cronológico fijo, ni semanal ni mensual. Por lo tanto, la segunda puntualización que debe hacerse respecto a lo ya publicado es que ni todas las crónicas cumplían con una periodización diaria ni estaban dispuestas en primera página ${ }^{79}$.

Por otra parte, el número de crónicas árabes experimenta una tendencia ascendente entre septiembre de 1906 (60 textos entre septiembre y diciembre) y diciembre de 1908, con un sensible descenso en 1909 y el máximo alcanzado en 1910 (305 textos, además de 10 suplementos: de 20 de enero, 30 de abril, 10 y 20 de mayo, 10 y 30 de junio, 31 de octubre, 15 y 30 noviembre y 15 de diciembre). A partir de entonces se aprecia un descenso paulatino hasta las últimas 25 crónicas, publicadas entre enero y abril de 1915.

Tomando como punto de partida la digitalización de los ejemplares disponibles a través de la web de la Biblioteca Virtual de Prensa Histórica, conviene advertir la dificultad que presenta su lectura en algunos casos debido al mal estado de conservación de las páginas, a la baja pixelación de las imágenes en el único formato disponible (pdf), y al hecho de que los textos aparecen borrosos o bien prácticamente ininteligibles por el desgaste de la tinta. Todas estas circunstancias resultan especialmente complejas para la escritura árabe en sus diferentes variantes, ya que se dispone en grupos consonánticos cuya única diferencia consiste en el número o disposición espacial de puntos y lo que conocemos como acentos circunflejos y anti-circunflejos (o circunflejos invertidos).

destacados en torno a la defensa o rechazo de la actuación militar y de la continuidad de la empresa colonial en el territorio marroquí.

77. Véanse «Noticias de Ceuta" (El Telegrama del Rif, 19 de febrero de 1908, p. 2 de la que, con carácter excepcional se ofrece a continuación su traducción castellana), o "Noticias de Mequinez" (El Telegrama del Rif, 1 de octubre de 1910, p. 3).

78. Baste como ejemplo el año de 1915: diez crónicas en enero (días 1, 4, 8, 14, 16, 17, 20, 21, 25 y 26), cinco en febrero (días 1, 2, 10, 12 y 19), siete en marzo (días 1, 3, 15, 16, 19, 22 y 25), y tres en abril (días 4, 11 y 26).

79. Madariaga, María Rosa de: Abd el-Krim el Jatani. La lucha por la independencia. Madrid: Alianza, 2009, p. 68. 


\section{ROCÍO VELASCO DE CASTRO}

MARRUECOS, 1911: EN TORNO A LA CRISIS DE AGADIR Y LAS CRÓNICAS

DE ABDELKRIM EN EL TELEGRAMA DEL RIF (MAYO-NOVIEMBRE DE 1911)

Las crónicas están escritas en árabe marroquí, como muestra la alteración del cuerpo consonántico de las letras "fā" (en árabe con un unto arriba, $\dot{\boldsymbol{\theta}}$, y en ára-

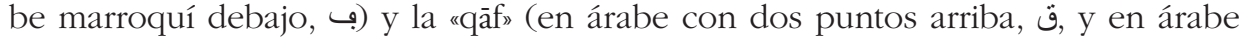
marroquí con uno solo, ف ف ( $^{80}$. Esta característica se observa, entre otros muchos ejemplos, en la transliteración de palabras de uso frecuente como Francia, y en la mención de personajes tan conocidos como el Gran Visir, Muhammad b. Abdessalam al-Muqri (citado en fuentes españolas como Moqri) ${ }^{81}$. Asimismo, el uso de la «ḍād» en sustitución de la «sīn» en el adjetivo «español/a» es otra característica del árabe marroquí que se traslada al texto escrito para indicar, en este y otros casos, el tipo de cambio establecido ese día para el rial (o duro hasaní), tanto a moneda española como francesa ${ }^{82}$.

Haciendo uso de una tipografía muy simple y de la tradicional ausencia del cuerpo vocálico, los textos reproducen la terminología característica del siglo XIX y principios del siglo xx, como puede colegirse del empleo de Marrâkuš (Marrakech) y no de al-Magrib para hacer referencia a "Marruecos". Asimismo, presenta algunas rupturas de palabra entre renglones que son impropias del árabe, pero muy comunes en imprentas o, como en este caso, en medios de prensa ajenos a esta lengua, cuya presencia resulta a todas luces, marginal.

El 1 de marzo de 1927, El Telegrama del Rif publicaba un número conmemorativo de la celebración de sus primeros veinticinco años de vida. Entre los redactores y colaboradores recordados se hizo mención a Abdelkrim, cuya labor propagandística de la causa española se rememoró con una serie de fragmentos seleccionados encabezados por el siguiente texto:

Lo que escribió Abd-el-Krim sobre la acción de España

Los lectores saben que durante algunos años figuró en la redacción el ex Rogui que tan mal pago dió a los beneficios que él y su familia recibieron de España, y como hoy se ponen en sus labios juicios poco halagadores para nuestra Nación, consideramos de actualidad reproducir algunos de sus escritos ${ }^{83}$

Como resultaría lógico colegir, se trata de unos textos destinados a adoctrinar al lector marroquí sobre el carácter benefactor y las ventajas de la penetración española en el territorio. El discurso giraba en torno a la necesaria modernización como motor de cambio y mejora social. Dicha modernización vendría de la mano del colonizador, a través de una serie de medidas enfocadas en los ámbitos económico y cultural.

80. Para más información sobre las peculiaridades gráficas que presenta el registro conocido como árabe marroquí estándar, véase Moscoso García, Francisco: "La pentaglosia en Marruecos. Propuestas para la estandarización del árabe marroquín, Miscelánea de Estudios Árabes y Hebraicos, 59, 2010, pp. 59-60.

81. A título ilustrativo, véase "Francia en Marruecos», El Telegrama del Rif, 1 de abril de 1911, p. 1 , en el que aparecen ambos términos.

82. El término empleado en árabe es "hasaní", como puede leerse, entre otros muchos textos, al final de la información árabe de la edición de 29 de septiembre de 1906.

83. El Telegrama del Rif, 1 de marzo de 1927, p. 6 
Junto a la hermandad hispano-rifeña y la oportunidad que se le brindaba a la región para salir del atraso en el que se encontraban, el tercer vector de su intervención discurría por los derroteros clásicos del colonialismo español: la retórica anti-francesa, para mayor agrado de los responsables políticos españoles del momento.

En la edición de 1911, El Telegrama del Rif ampliaba de cuatro a seis columnas su formato y se publicaba sin suplemento árabe (el último databa de 15 de diciembre de 1910), pero sí con un número extraordinario en esta lengua con motivo de la visita del rey Alfonso XIII a la ciudad que, al publicarse en fecha anterior a la ocupación francesa de Fez, ha quedado al margen del corpus. La visita, que tenía como objetivo contrarrestar los efectos de la estrepitosa derrota en Barranco del Lobo, volvería a repetirse una década más tarde tras la debacle de Annual.

Todas las características anteriormente mencionadas están presentes en el corpus consultado para el periodo en el que tuvo lugar la crisis de Agadir. Este último comprendería oficialmente desde el 21 de mayo (entrada de las tropas francesas en Fez) hasta el 4 de noviembre (acuerdo franco-alemán) de 1911, aunque nos hemos remontado también a la crónica del día 20, en la que se dedica a exponer el avance de las tropas francesas, la ocupación de Mehdía (en Kenitra), así como sus enfrentamientos con algunas harcas bereberes ${ }^{84}$. Y aunque no figure en el cuadro, se ha extendido la lectura al 7 de noviembre, ya que se esperaba encontrar una correspondencia directa entre el editorial, dedicado a las consecuencias de la crisis de Agadir para España y Francia, y la crónica árabe. El vaciado se ha realizado a partir de un volumen total de 140 crónicas distribuidas como sigue (Tabla 1):

Tabla 1. El Telegrama del Rif. Crónicas árabes durante la Crisis de Agadir

(21 DE MAYO-4 DE NOVIEMBRE DE 1911)

\begin{tabular}{|l|c|c|l|}
\hline \multicolumn{1}{|c|}{ MES } & \multicolumn{1}{c|}{ PERÍODO } & CRÓNICAS & \multicolumn{1}{c|}{ Días } \\
\hline Mayo & $21-31 / 05 / 1911$ & 9 & $21,23-28,30$ y 31 \\
\hline Junio & $01-30 / 06 / 1911$ & 24 & $1-4,6-11,13-15,17-18$ y 20-30 \\
\hline Julio & $01-30 / 07 / 1911$ & 27 & $1-2,4-9,11-16,18-23$ y 25-30 \\
\hline Agosto & $01-31 / 08 / 1911$ & 26 & $1-6,8-13,14-20,22-26$ y 29-31 \\
\hline Septiembre & $01-30 / 09 / 1911$ & 23 & $1-3,5-10,12-14,16-17,19,21-23$ y 26-30 \\
\hline Octubre & $01-31 / 10 / 1911$ & 27 & $1,3-15,17-22,24-29$ y 31 \\
\hline Noviembre & $01-04 / 11 / 1911$ & 4 & $1-4$ \\
\hline
\end{tabular}

Fuente: Elaboración propia.

84. Se utiliza el término «bereber" y no "amazigh", como se estila actualmente en los estudios descolonizadores porque es el empleado en árabe por Abdelkrim, acorde a su época, y porque de esta forma se evita realizar una lectura anacrónica de los hechos y del lenguaje empleado en el relato de los acontecimientos. 


\section{EL TELEGRAMA DEL RIF: AGADIR y LAS CRÓNICAS DE ABDELKRIM}

En 1911, las disensiones entre Francia y España por la cuestión marroquí también se vieron reflejadas en la prensa ${ }^{85}$. Tomando los acontecimientos que dieron lugar a la génesis y evolución de la crisis de Agadir como punto de partida, los medios franceses y españoles defensores de la intervención y colonización del continente africano no escatimaron esfuerzos en plasmar en sus crónicas y editoriales su defensa de los intereses nacionales. Así rezaba la cabecera de El Telegrama del Rif: Diario ajeno a la política. Defensor de los intereses de España en Marruecos.

Dejando a un lado la contradicción inherente a su supuesta desvinculación de la política, la línea editorial de este periódico, como ya se ha comentado, lo situaba en primera línea de las publicaciones españolas de carácter militar, africanista y abiertamente colonialista de la época. De ahí que su lectura y análisis, incluyendo las crónicas árabes de Abdelkrim, reviertan un especial interés para entender el diseño y ejecución de la propaganda colonial y su mayor o menor incidencia en la opinión pública.

El primer elemento destacable es la alternancia de narraciones más extensas con breves sucesiones de noticias, casi a modo de titulares. La edición del 21 de mayo es un buen ejemplo de ello, porque también deja entrever la priorización temática con un claro protagonista: la acción diplomática y militar francesa en Larache, y un doble objetivo: ensalzar la hermandad española y sembrar la inquietud y preocupación ante las actuaciones francesas en el territorio.

Así, en primer lugar, se informaba de la llegada del capitán Moreaux al mando de una tropa nutrida con efectivos marroquíes a las proximidades de Larache y de la intención del cónsul francés de que fuesen acogidos en la ciudad. A continuación, se hacía eco a los lectores de que el pretendiente al trono, Muley al-Zayn, había enviado a todas las cancillerías de Tánger una nota solicitando su reconocimiento oficial como sultán tras haberse celebrado en Mequinez su beia o juramento de fidelidad con el que son proclamados los sultanes marroquíes. Efectivamente, como se ha comentado en líneas anteriores, dicha ceremonia había tenido lugar en abril. También se comentaba la difícil situación del sultán Muley Abdelhafid en Fez y la necesidad de contar con fuerzas extranjeras para protegerlo ante la gravedad de la situación. Y cerrando la crónica, se recogía la llegada de una delegación de las cabilas de Anyera a Ceuta para entrevistarse con el general Alfau y transmitirle un mensaje de agradecimiento a S.M. Alfonso XIII ${ }^{86}$ en respuesta a las felicitaciones recibidas con motivo de la fiesta del Mulud.

85. García DE JuAn, Miguel Ángel: «Enfrentamiento de la prensa de España y Francia por la cuestión marroquí en 1911 (un nuevo capítulo de las disensiones entre los dos países)", Espacio, Tiempo y Forma. Serie V Historia Contemporánea, 30, 2018, pp. 189-224.

86. El Telegrama del Rif, 21 de mayo de 1911, p. 1. En el original árabe consta por error Alfonso III. 
Este contraste se hace todavía más patente en la edición del 23 de mayo. Frente a las peticiones de la creación de un binterland para Melilla, con especial atención a la salvaguarda de las actividades portuarias, y a la columna «El socorro de Fez", en la que se reconoce la necesaria intervención de los franceses y se disculpa la lentitud de su avance por la acometividad de las tribus levantadas en rebeldía, la información árabe dedica la mitad de su espacio a rememorar la fiesta celebrada en Tetuán con motivo de la efeméride de la entronización de Alfonso XIII y el resto a resumir los combates acontecidos entre franceses y cabileños en las proximidades del río Muluya, cuyo paso era necesario para llegar hasta $\mathrm{Fez}^{87}$. De nuevo la dicotomía entre ambos países está muy presente en la imagen que se quiere transmitir al lector marroquí.

Una primera oportunidad para comprobar hasta qué punto se condicionaba al lector marroquí la encontramos en la sucesión de crónicas que van del 27 al 31 de mayo $^{88}$, donde la carga propagandística va in crescendo a medida que se describen los hechos que llevaron a la llegada, entrada y ocupación de Fez por parte de las tropas francesas. Así, en la edición del día 27 la balanza de la parcialidad se inclina claramente por el texto "Fez por los franceses", en el que se afirma abiertamente que los disturbios fueron provocados por agentes al servicio de Francia y que el momento elegido para ocupar la capital, en plena recogida de la cosecha, había evitado que el enfrentamiento con las tribus fuese mayor. Es decir, había premeditación, violencia y ambición en la actuación francesa, no un afán modernizador (léase civilizador) y de mejora de la sociedad hermana como se insistía, era el objetivo de España.

En la Información Árabe se da buena cuenta de ello bajo el siguiente titular: «Las tropas francesas ocupan Fez, la capital». Abdelkrim recoge que desde Tánger llegaban noticias de que "la mehala del coronel Brulard habían ocupado con gran facilidad los alrededores de la ciudad" mientras las tropas de Moinier habían avanzado desde Casablanca hacia Fez "para hacer frente a las tribus que se habían rebelado contra el sultán Abdelaziz» ${ }^{89}$. La información concluye asegurando que ambas fuerzas se habrían unido con el objetivo de acabar con la rebelión.

En los albores de la campaña del Kert, contamos con una primera alusión a Amizzián, del que el 1 de junio se daba la noticia "Batalla en torno al Muluya: Amizzián herido» 90 . Entre otros datos se informaba de lo siguiente: «El 20 de mayo se libró una gran batalla en el interior de la cabila de Beni Bu Ifruh entre las harkas de las tribus cercanas al Muluya y las tropas francesas [...] Hay un gran número

87. El Telegrama del Rif, 23 de mayo de 1911, p. 1.

88. El Telegrama del Rif, 27 de mayo de 1911, p. 1; 28 de mayo de 1911, p. 1; 30 de mayo de 1911, p. 1; 31 de mayo de 1911, p. 1.

89. El Telegrama del Rif, 27 de mayo de 1911, p. 1.

90. El Telegrama del Rif, 1 de junio de 1911, p. 1. 


\section{ROCÍO VELASCO DE CASTRO \\ MARRUECOS, 1911: EN TORNO A LA CRISIS DE AGADIR Y LAS CRÓNICAS \\ DE ABDELKRIM EN EL TELEGRAMA DEL RIF (MAYO-NOVIEMBRE DE 1911)}

de heridos, entre ellos Muhammad Amizzián» 91 del que se dice que ha perdido la movilidad de una de sus manos.

Este último apunte sobre la suerte de Amizzián, dejando a un lado que se trata de un hecho histórico incontestable, vuelve a servir a la propaganda española para trasladar al lector marroquí la idea de que, pese a que combate contra españoles y franceses, serían únicamente estos últimos los que emplearían la violencia contra sus compatriotas. Al igual que va a suceder con el jerifismo de Raisuni, tampoco Amizzián es reconocido o mencionado con los títulos con los que suele aparecer cuando se redacta en árabe, algo llamativo y que puede obedecer a una estrategia encaminada al desprestigio de ambos.

Hasta el 4 de julio no aparecieron noticias relativas a Agadir y a la respuesta alemana a la ocupación francesa de Fez. En el marco de un genérico «Sobre la situación del vecino imperio" se agruparon dos noticias. La primera, en la que se confirma la ocupación de Fez y Mequinez por parte de las tropas francesas, termina de nuevo con la amenaza que supone su presencia en Alcazarquivir, en cuyo puerto seguían muy interesados. La segunda es una de las más relevantes para el periodo que nos ocupa.

Bajo el titular «Una nueva ocupación militar en Marruecos: tropas alemanas en Agadir ${ }^{92}$, se da cuenta del comunicado emitido desde Berlín informando del motivo que ha llevado al cañonero alemán a fondear en la costa de Agadir: la protección de los derechos de sus nacionales en el desarrollo de sus operaciones e intereses comerciales en todo el conjunto del territorio marroquí, de acuerdo con lo estipulado en el Acta de Algeciras y bajo los auspicios del gobierno marroquí.

Desde Berlín, la capital alemana, ha llegado un telegrama en el que se informa de que el gobierno alemán ha enviado un buque de guerra al puerto de Agadir con el objetivo de proteger al gobierno de la zona [...] El envío de este cañonero junto al desembarco de tropas distribuidas en torno al puerto ha sido la respuesta alemana ante la debilidad que presentaba la seguridad de un enclave de gran importancia para la actividad comercial. Alemania enmarca esta medida en sus derechos según lo estipulado en el Acta de la Conferencia de Algeciras ${ }^{93}$.

El texto resulta bastante aséptico y se limita a resumir la versión alemana sin emitir ningún juicio de valor, aunque sí es cierto que reproduce la versión alemana. El único elemento que puede apreciarse como disonante respecto al contenido es el titular con el que se abre la crónica, ya que introduce una crítica nada velada que no se correspondería con el desarrollo de la noticia. En este sentido, la equiparación un tanto forzada pero evidente de la presencia francesa en Alcazarquivir con la alemana en Agadir lleva de nuevo a la concepción ficticia pero efectiva, del hecho diferencial español frente al resto de países europeos.

91. Ibidem.

92. El Telegrama del Rif, 4 de julio de 1911, p. 1.

93. Ibidem. 
En esta clave, y con la supuesta espontaneidad de movimientos atribuida a los españoles, ha de analizarse la justificación que se hace de la versión oficial sobre la ocupación militar de Larache y Alcazarquivir. En la edición del 5 de julio volvía a constatarse esta circunstancia. Mientras se informa de la deserción entre las fuerzas francesas de un nutrido grupo de cuarenta cabileños, la crónica terminaba informando del movimiento de tropas españolas en las proximidades de Alcazarquivir y haciendo hincapié en el buen recibimiento dispensado por una mehala de Raisuni, del que, como se había adelantado, no se menciona su rango ni su título de jerife con el que habitualmente es citado ${ }^{94}$.

La segunda mención a las maniobras alemanas data del 8 de julio. Con el título "Alemania en Marruecos. Sus y su capital, Tarudant»" ${ }^{95}$, se informa del interés que ha despertado la zona en los alemanes y del interés estratégico que supondría para ellos consolidar el control del puerto de Agadir y desde allí establecer un centro de operaciones que se extendiera al interior del territorio. Ello se enmarcaba, en efecto, en el contexto de las conversaciones mantenidas por una serie de representantes alemanes, entre ellos los hermanos Mannesmann, con el bajá de Tarudant con la intención de crear una zona de influencia en la región. Aunque el texto se centra en subrayar la importancia del enclave, "sito a 90 kilómetros del Agadir» y "repleto de almendros, nogales y olivos" 96 plantea como un hecho casi consumado que Alemania habría llegado para quedarse, al menos hasta la celebración de una nueva conferencia internacional. El texto volvió a publicarse sin cambio alguno en las ediciones de los días 12 y 13 de ese mismo mes de julio ${ }^{97}$.

A partir de entonces se observa prácticamente un vacío en torno a Agadir a pesar de que en el periódico seguía el estado de las negociaciones entre Francia y Alemania ${ }^{98}$. La campaña del Kert y la ocupación de Ifni centraron las crónicas árabes junto a algunos sucesos o noticias de menor calado. En esta dinámica se llegaba al mes de noviembre. Ultimadas las negociaciones franco-alemanas y pendientes únicamente de consensuar el texto del acuerdo rubricado oficialmente el día 4, El Telegrama del Rif se volcaba con el «affaire Oujda». En plena pugna entre civiles y militares por hacerse con la gestión de la administración colonial, estallaba un caso de posible corrupción ante la sospecha de malversación de fondos públicos por parte de funcionarios franceses y marroquíes. La amplia cobertura dispensada a este asunto, también en el caso de la crónica árabe ${ }^{99}$, revelaría de nuevo la priorización de noticias y su intencionalidad: reforzar ante el lector marroquí la

94. El Telegrama del Rif, 5 de julio de 1911, p. 1. A pesar de que en árabe es "Raisuni» (يوسنوسيرل), Abdelkrim lo escribe como la mayoría de los españoles de la época: "al-Raisuli» (يلنوسيرل).

95. El Telegrama del Rif, 8 de julio de 1911, p. 1.

96. Ibidem.

97. El Telegrama del Rif, 12 de julio de 1911, p. 1; 13 de julio de 1911, p. 1.

98. Véase como ejemplo «Francia y Alemania». El Telegrama del Rif, 13 de septiembre de 1911, p. 1; "Francia-Alemania. Las negociaciones en su momento crítico». El Telegrama del Rif, 16 de septiembre de 1911, p. 1.

99. El Telegrama del Rif, 4 de noviembre de 1911, p. 1. 
diferencia entre franceses y españoles y centrar el rechazo a la ocupación colonial en los primeros.

Otro aspecto significativo es que durante estos meses haya una presencia de noticias internacionales (revuelta de Yemen, avance de las tropas italianas en Libia, etc. ${ }^{100}$. Sin embargo, no se incluyó ninguna observación o noticia sobre el tratado franco-alemán con el que se dio por finalizado el episodio de Agadir. La única explicación plausible es que España, fuera de cualquier negociación, prefería concentrarse en tratar de consolidar sus posiciones en el territorio. Por ello, y a pesar de recoger la noticia de la retirada del Berlín de las costas de Agadir y de plantearse una serie de interrogantes en torno a la política alemana y la situación de Marruecos, la crónica árabe de ese día se centraba en la situación en el Rif sin arrojar ninguna información relevante a lo ya sabido ${ }^{101}$.

Y lo mismo sucedía el 7 de noviembre. Mientras el editorial «España y Francia" se dedicaba a analizar las consecuencias de la crisis de Agadir a través de lo que se comentaba en la prensa francesa con mención a lo pactado en el convenio franco-español de 1904 y al acuerdo franco-alemán de 1911, en el texto árabe, que se encuentra en mal estado de conservación, no se hacía alusión alguna, tampoco en días anteriores, a ninguno de los dos acuerdos ${ }^{102}$. En su lugar, y de nuevo con el Rif en mente, se dedica a reproducir el listado de musulmanes que se habían adherido a las tropas españolas en su lucha contra el levantamiento rifeño ${ }^{103}$. Toda una paradoja que nos lleva a plantear, cuando se cumple el primer centenario del desastre de Annual, la pertinencia de emprender un estudio más detallado centrado en la percepción que Abdelkrim habría transmitido en El Telegrama del Rif del movimiento liderado por su antecesor en la lucha contra los españoles.

\section{CONCLUSIONES}

A lo largo de este recorrido se ha tratado de exponer la convulsa y compleja coyuntura en la que tuvo lugar la crisis de Agadir (1911) y cómo dicho episodio resultó crucial para la implantación del régimen de protectorado en Marruecos, además de constituirse en antesala de la primera guerra mundial. Las consecuencias de Agadir podrían resumirse en el refuerzo de la Entente Cordiale, que consolidó la hegemonía francesa en el norte de África. A nivel interno, ni la Conferencia de Algeciras ni la crisis de 1911 evitaron la capitulación de Muley Abdelhafid, escenificada un año más tarde en la firma del tratado de Fez y poco después, en su renuncia al trono. También sirvió para evidenciar el carácter marginal de España y

100. El caso libio es significativo porque coinciden el editorial en español y la crónica árabe en centrarse en los avances italianos en el territorio. El Telegrama del Rif, 8 de noviembre, p. 1.

101. El Telegrama del Rif, 5 de noviembre de 1911, p. 1.

102. El Telegrama del Rif, 7 de noviembre de 1911, p. 1.

103. El Telegrama del Rif, 8 de noviembre de 1911, p. 1. 
sus dificultades para hacer frente a las ambiciones expansionistas francesas y a la resistencia armada marroquí.

La paulatina entrada en escena del clan de los Jattabi en el desenlace de acontecimientos desde su posición de "moros pensionados" hasta desembocar en abrupta ruptura que condujo al enfrentamiento armado, se revela en estos años a través de la labor propagandística de Abdelkrim en las páginas de El Telegrama del Rif. En ellas se muestra como un fiel colaborador, sin ambages ni altibajos en su defensa de la empresa colonial española.

En relación con su inestimable difusión de dicha causa, y teniendo en cuenta que el mero hecho de publicar sobre una determinada temática o noticia, o de dar a conocer una información y obviar otra ya supone una selección de los contenidos, y con ello, una intencionalidad, ¿hasta qué punto el rifeño tuvo capacidad de decisión en la elección de qué era noticiable y conveniente difundir en cada momento al lector marroquí?; ¿se trataba de redacciones originales o de traducciones a las que les daba un toque personal al traducirlas al árabe? En ambos casos, atribuirle una total libertad en la toma de decisiones posiblemente sería ir demasiado lejos.

De hecho, habida cuenta sus buenas relaciones con británicos y alemanes, la cuestión de si Abdelkrim habría adoptado una toma de posesión más neutra, o cuanto menos ambigua en sus crónicas periodísticas durante la crisis de Agadir habría quedado resuelta al confirmarse su completa correspondencia con la línea editorial de los responsables del periódico. En lo que a la posición alemana se refiere, cabría concluir señalando la escasa relevancia de sus escritos, como también lo fue el papel que desempeñó España en la crisis de Agadir, objeto de estudio de estas páginas. 